\title{
INTERACTION OF PENTAPHENYLANTIMONY WITH ACETYLENEDICARBOXYLIC ACID. MOLECULAR STRUCTURE OF BIS(TETRAPHENYLANTIMONY) ACETYLENEDICARBOXILATE
}

\author{
V.V. Sharutin, vvsharutin@rambler.ru \\ O.K. Sharutina, sharutinao@mail.ru \\ Yu.O. Gubanova, ulchik7757@mail.ru \\ South Ural State University, Chelyabinsk, Russian Federation
}

\begin{abstract}
Bis(tetraphenylantimony) acetylenedicarboxilate (1) has been synthesized by the interaction of pentaphenylantimony with acetylenedicarboxylic acid (mole ratio 2:1 or $1: 1)$ in toluene. In molecule 1 the acid anion has the bridging role and bonds $\mathrm{Ph}_{4} \mathrm{Sb}$ fragments. The antimony atoms have distorted trigonal bipyramidal coordination with the oxygen atom in the axial position. The $\mathrm{Sb}-\mathrm{O}$ bond lengths are 2.287(4) and 2.389(4) $\AA$, the Sb-C bond lengths are 2.110(7)-2.179(6) $\AA$ and 2.108(6)-2.165(6) $\AA$.

Keywords: pentaphenylantimony, acetylenedicarboxylic acid, bis(tetraphenylantimony) acetylenedicarboxilate, molecular structure, X-ray diffraction analysis.
\end{abstract}

\section{Introduction}

It is known that the interaction of pentaarylantimony with dicarboxylic acid can give two types of compounds: acidic tetraarylantimony carboxilates and bis(tetraarylantimony) carboxilates [1-4]. According to the X-ray diffraction data, the coordination of antimony atoms in these types of molecules is significantly different. In the first case there is a tendency of the $\mathrm{Ar}_{4} \mathrm{Sb}$ fragment to the transformation into the tetrahedric configuration, which is accompanied by increase of the distance between the antimony atom and the oxygen atom of the monodentate carboxylic ligand, which has the bond of coordinating character [1-3].

In binuclear bis(tetraarylantimony) carboxilates the antimony atom has a slightly distorted trigonal bipyramidal coordination $\left[\mathrm{SbC}_{4} \mathrm{O}\right]$. As a rule, the bridging carboxilyc ligand has anisobidental type of coordination caused by intramolecular interactions $\mathrm{Sb} \cdots \mathrm{O}=\mathrm{C}$ between the antimony atoms and carbonyl oxygen atoms [2, 4-6]. Only oxalate ligand is coordinated to the antimony atom almost symmetrically, thus the antimony atom coordination transforms into the octahedral one [7].

In the continuation of our research of organoantimony dicarboxylic acid derivatives the reactions of pentaphenylantimony with acetylenedicarboxylic acid have been studied. The product structure has been determined by the X-ray diffraction analysis.

\section{Experimental}

Interaction of pentaphenylantimony with acetylenedicarboxylic acid. A) A mixture of $0.200 \mathrm{~g}$ $(0.394 \mathrm{mmol})$ of pentaphenylantimony and $0.022 \mathrm{~g}(0.197 \mathrm{mmol})$ of acetylenedicarboxylic acid in $5 \mathrm{~mL}$ of toluene was kept in a sealed glass ampoule at room temperature for $24 \mathrm{~h}$. The solution was concentrated, the crystals were filtered off and dried. The substance was isolated as $0.173 \mathrm{~g} \mathrm{(90 \% )} \mathrm{of} \mathrm{colorless}$ crystals 1 with $\mathrm{T}_{\text {dec }}=178{ }^{\circ} \mathrm{C}$. Found, \%: C 64.09; $\mathrm{H}$ 4.23. For $\mathrm{C}_{52} \mathrm{H}_{40} \mathrm{O}_{4} \mathrm{Sb}_{2}$, anal. calcd, \%: $\mathrm{C} 64.20 ; \mathrm{H}$ 4.11. IR spectrum $\left(v, \mathrm{~cm}^{-1}\right): 3401,3057,2989,1632,1612,1577,1479,1435,1389,1322,1289,1184$, $1158,1067,1021,996,774,731,691,670,460$.

B) A mixture of $0.200 \mathrm{~g}(0.394 \mathrm{mmol})$ of pentaphenylantimony and $0.044 \mathrm{~g}(0.394 \mathrm{mmol})$ of acetylenedicarboxylic acid in $5 \mathrm{~mL}$ of toluene was heated in a sealed glass ampoule in a boiling water bath for $15 \mathrm{~min}$. Large crystals of bis(tetraphenylantimony) carbonate with $\mathrm{T}_{\mathrm{m}}=234^{\circ} \mathrm{C}$ were observed on the ampoule walls during cooling. IR spectrum $\left(v, \mathrm{~cm}^{-1}\right)$ : 3050, 1577, 1472, 1429, 1382, 1332, 1304, 1264 , 1186, 1157, 1067, 1021, 997, 830, 730, 691, 653, 457.

The supernatant toluene solution was concentrated, the crystals were filtered off and dried. The substance was isolated as $0.149 \mathrm{~g}(76 \%)$ of colorless crystals of tetraphenylantimony propiolate with 


\section{Organometallic chemistry}

$\mathrm{T}_{\mathrm{m}}=174{ }^{\circ} \mathrm{C}$ (with decomposition). Found, (\%): $\mathrm{C}$ 64.81; H 4.29. For $\mathrm{C}_{27} \mathrm{H}_{21} \mathrm{O}_{2} \mathrm{Sb}$, anal. calcd, (\%): $\mathrm{C}$ 64.96; H 4.21. IR spectrum ( $\left.v, \mathrm{~cm}^{-1}\right): 3277,3053,3010,2990,2917,2591,2361,2178,2091,1967$, $1885,1819,1621,1575,1562,1477,1433,1377,1333,1301,1187,1158,1070,1057,1020,997,883$, $782,737,693,658,643,601,586,462,447$.

IR spectra were recorded in $\mathrm{KBr}$ pellets on the IR Fourier-transform spectrometer Bruker Tensor 27.

The X-ray diffraction analyses of crystal 1 was performed on the Bruker D8 Quest diffractometer (Mo $\mathrm{K}_{\alpha}$-radiation, $\lambda=0.71073 \AA$, graphite monochromator). The data collection and editing as well as the refinement of unit cell parameters and the absorption accounting were carried out using SMART and SAINT Plus program packages [8]. All calculations for the structure determination and refinement were carried out using the SHELXTL/PC [9] and OLEX2 [10] programs packages. The structures were determined by the direct method and refined by least-squares method calculations in anisotropic approximation for non-hydrogen atoms. Selected crystallographic data and structure refinement results for compounds I and II are given in Table 1, and selected bond lengths and bond angles are listed in Table 2.

The full tables of atomic coordinates, bond lengths, and bond angles were deposited with the Cambridge Crystallographic Data Centre (CCDC 994821; deposit@ccdc.cam.ac.uk; http://www.ccdc.cam.ac.uk).

Table 1

Crystallographic data and the experimental and structure refinement parameters for compound 1

\begin{tabular}{|c|c|}
\hline Parameter & Value \\
\hline Empirical formula & $\mathrm{C}_{52} \mathrm{H}_{40} \mathrm{O}_{4} \mathrm{Sb}_{2}$ \\
\hline Formula weight & 972.34 \\
\hline$T, \mathrm{~K}$ & $296(2)$ \\
\hline Crystal system & Monoclinic \\
\hline Space group & $\mathrm{P} 2{ }_{1} / \mathrm{c}$ \\
\hline$a, \AA$ & $10.0115(4)$ \\
\hline$b, \AA$ & $21.1868(8)$ \\
\hline$c, \AA$ & $22.6148(9)$ \\
\hline$\alpha, \operatorname{deg}$ & 90.00 \\
\hline$\beta, \operatorname{deg}$ & $91.530(2)$ \\
\hline$\gamma, \operatorname{deg}$ & 90.00 \\
\hline$V, \AA^{3}$ & $4795.2(3)$ \\
\hline$Z$ & 4 \\
\hline$\rho$ (calcd.), $\mathrm{g} / \mathrm{cm}^{3}$ & 1.347 \\
\hline$\mu, \mathrm{mm}^{-1}$ & 1.167 \\
\hline$F(000)$ & 1944.0 \\
\hline Crystal size, $\mathrm{mm}$ & $0.92 \times 0.18 \times 0.09$ \\
\hline $2 \theta$ Range of data collection, deg & $6.64-46.62^{\circ}$ \\
\hline Range of refraction indices & $-9 \leq \mathrm{h} \leq 11,-23 \leq \mathrm{k} \leq 22,-25 \leq 1 \leq 23$ \\
\hline Measured reflections & 12802 \\
\hline Independent reflections & 6525 \\
\hline$R_{\text {int }}$ & 0.0282 \\
\hline Refinement variables & 523 \\
\hline GOOF & 1.095 \\
\hline$R$ factors for $\mathrm{F}^{2}>2 \sigma\left(\mathrm{F}^{2}\right)$ & $R_{1}=0.0401, w R_{2}=0.1132$ \\
\hline$R$ factors for all reflections & $R_{1}=0.0576, w R_{2}=0.1226$ \\
\hline Residual electron density (min/max), $e / \AA^{3}$ & $1.02 /-0.41$ \\
\hline
\end{tabular}


Selected bond lengths and bond angles in the structure of compound 1

\begin{tabular}{|c|c|c|c|}
\hline Bond & $d, \AA$ & Angle & $\omega$, deg \\
\hline $\mathrm{Sb}(1)-\mathrm{O}(1)$ & $2.287(4)$ & $\mathrm{C}(1) \mathrm{Sb}(1) \mathrm{O}(1)$ & $84.7(2)$ \\
\hline $\mathrm{Sb}(1)-\mathrm{C}(1)$ & $2.110(7)$ & $\mathrm{C}(1) \mathrm{Sb}(1) \mathrm{C}(31)$ & $96.7(2)$ \\
\hline $\mathrm{Sb}(1)-\mathrm{C}(31)$ & $2.179(6)$ & $\mathrm{C}(1) \mathrm{Sb}(1) \mathrm{C}(11)$ & $114.6(2)$ \\
\hline $\mathrm{Sb}(1)-\mathrm{C}(11)$ & $2.118(6)$ & $\mathrm{C}(1) \mathrm{Sb}(1) \mathrm{C}(21)$ & $174.6(2)$ \\
\hline $\mathrm{Sb}(1)-\mathrm{C}(21)$ & $2.133(6)$ & $\mathrm{C}(31) \mathrm{Sb}(1) \mathrm{O}(1)$ & $81.91(18)$ \\
\hline $\mathrm{Sb}(2)-\mathrm{O}(3)$ & $2.389(4)$ & $\mathrm{C}(11) \mathrm{Sb}(1) \mathrm{O}(1)$ & $93.3(2)$ \\
\hline $\mathrm{Sb}(2)-\mathrm{C}(51)$ & $2.108(6)$ & $\mathrm{C}(11) \mathrm{Sb}(1) \mathrm{C}(31)$ & $85.49(19)$ \\
\hline $\mathrm{Sb}(2)-\mathrm{C}(41)$ & $2.119(6)$ & $\mathrm{C}(11) \mathrm{Sb}(1) \mathrm{C}(21)$ & $97.3(2)$ \\
\hline $\mathrm{Sb}(2)-\mathrm{C}(61)$ & $2.102(6)$ & $\mathrm{C}(21) \mathrm{Sb}(1) \mathrm{O}(1)$ & $89.54(19)$ \\
\hline $\mathrm{Sb}(2)-\mathrm{C}(71)$ & $2.165(6)$ & $\mathrm{C}(21) \mathrm{Sb}(1) \mathrm{C}(31)$ & $119.6(2)$ \\
\hline $\mathrm{C}(7)-\mathrm{O}(1)$ & $1.293(7)$ & $\mathrm{C}(51) \mathrm{Sb}(2) \mathrm{O}(3)$ & $94.5(2)$ \\
\hline $\mathrm{C}(7)-\mathrm{O}(2)$ & $1.212(7)$ & $\mathrm{C}(51) \mathrm{Sb}(2) \mathrm{C}(41)$ & $82.4(2)$ \\
\hline $\mathrm{C}(10)-\mathrm{O}(3)$ & $1.255(7)$ & $\mathrm{C}(51) \mathrm{Sb}(2) \mathrm{C}(71)$ & $98.5(2)$ \\
\hline $\mathrm{C}(10)-\mathrm{O}(4)$ & $1.224(7)$ & $\mathrm{C}(41) \mathrm{Sb}(2) \mathrm{O}(3)$ & $\mathrm{C}(41) \mathrm{Sb}(2) \mathrm{C}(71)$ \\
\hline $\mathrm{Sb}(1) \cdots \mathrm{O}(2)$ & $3.297(6)$ & & \\
\hline
\end{tabular}

\section{Results and Discussion}

We have found that the reaction of pentaphenylantimony with dicarboxylic acid (mole ratio 2:1 or 1:1) proceeds in toluene solution at room temperature with the substitution of hydrogen atoms in two carboxyl groups and the formation of bis(tetraphenylantimony) acetylenedicarboxilate (1). The yield of compound $\mathbf{1}$ is up to $90 \%$ :

\section{$2 \mathrm{Ph}_{5} \mathrm{Sb}+\mathrm{HOC}(\mathrm{O}) \mathrm{C} \equiv \mathrm{CC}(\mathrm{O}) \mathrm{OH} \rightarrow \mathrm{Ph}_{4} \mathrm{SbOC}(\mathrm{O}) \mathrm{C} \equiv \mathrm{C}(\mathrm{O}) \mathrm{COSbPh}_{4}+2 \mathrm{PhH}$ 1}

Only one carboxyl group reacts with pentaphenylantimony after short-duration heating of equimolar quantities in toluene solution. The second group is decarboxylated in this case.

$$
\mathrm{Ph}_{5} \mathrm{Sb}+\mathrm{HOC}(\mathrm{O}) \mathrm{C} \equiv \mathrm{C}(\mathrm{O}) \mathrm{COH} \rightarrow \mathrm{Ph}_{4} \mathrm{SbOC}(\mathrm{O}) \mathrm{C} \equiv \mathrm{CH}+\mathrm{PhH}+\mathrm{CO}_{2}
$$

The yield of tetraphenylantimony propiolate isolated from the reaction mixture is $76 \%$. Its IR spectrum, melting point and parameters of crystal cell correspond to the similar characteristics of the compound synthesized from pentaphenylantimony and propiolic acid [11]. Bis(tetraphenylantimony) carbonate $\left(\mathrm{Ph}_{4} \mathrm{Sb}\right)_{2} \mathrm{CO}_{3}$ is the second product of this reaction with the yield about $10 \%$. This product has been identified by its melting point and IR spectrum. As shown by X-ray diffraction, the obtained bis(tetraphenylantimony) carbonate has triclinic modification described in the paper [12].

According to the X-ray diffraction data, the acid anion in molecule $\mathbf{1}$ has the bridging role and bonds $\mathrm{Ph}_{4} \mathrm{Sb}$ fragments. The $\mathrm{Sb}(1,2)$ atoms have distorted trigonal bipyramidal coordination with carboxylate and phenyl ligands in the axial positions (Fig. 1).

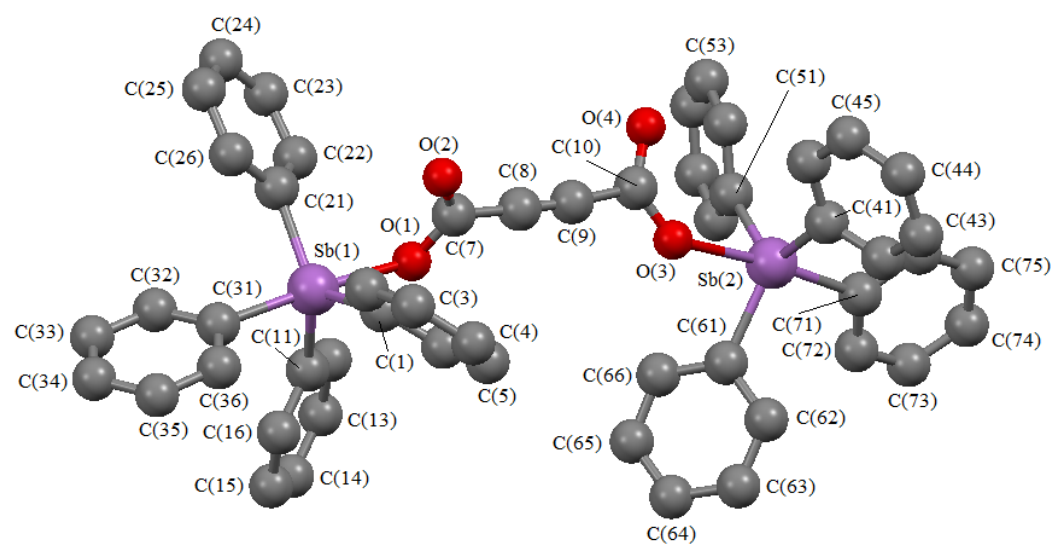

Fig. 1. The structure of compound 1 


\section{Organometallic chemistry}

The axial angles $\mathrm{OSb}(1,2) \mathrm{C}$ are equal to $175.2(2)^{\circ}$ and $174.7(2)^{\circ}$. The sums of the CSbC angles in the equatorial planes are $357.0(2)^{\circ}$ and $356.2(2)^{\circ}$, respectively. There is deviation of $\mathrm{Sb}(1,2)$ atoms from the equatorial plane towards the carbon atom in the axial position up to $0.218(2) \AA$ and $0.237(2) \AA$. The angles between the axial and equatorial bonds of $\mathrm{OSb}(1,2) \mathrm{C}$ are less than $90^{\circ}\left(81.9(2)-85.5(2)^{\circ}\right.$, $\left(78.8(2)-89.5(2)^{\circ}\right)$, for $\operatorname{CSb}(1,2) \mathrm{C}$ they are more than $90^{\circ}\left(93.3(2)-97.3(2)^{\circ}, 94.5(2)-98.5(2)^{\circ}\right)$. The length of $\mathrm{Sb}(1,2)-\mathrm{C}$ equatorial bonds changes in the ranges 2.110(7)-2.133(6) $\AA, 2.108(6)-2.119(6) \AA$. The axial distances $\mathrm{Sb}(1,2)-\mathrm{C}(2.179(6) \AA$ and $2.165(6) \AA)$ are greater than equatorial ones. The $\mathrm{Sb}(1)-\mathrm{O}(1)(2.287(4) \AA)$ and $\mathrm{Sb}(2)-\mathrm{O}(3)(2.389(4) \AA)$ bonds are longer than the sum of covalent radii of antimony and oxygen $(2.05 \AA[13])$. As one would expect, the $\mathrm{C}(7)-\mathrm{O}(1)(1.293(7) \AA \AA), \mathrm{C}(10)-\mathrm{O}(3)$ $(1.255(7) \AA)$ distances in the carboxyl group are greater than the $\mathrm{C}(7)-\mathrm{O}(2)(1.212(7) \AA)$ and $\mathrm{C}(10)-\mathrm{O}(4)$ (1.224(7) $\AA$ ) distances. In structure 1 bidentate properties of the carboxylate ligands almost do not appear. The intramolecular $\mathrm{Sb}(1) \cdots \mathrm{O}(2)$ and $\mathrm{Sb}(2) \cdots \mathrm{O}(4)$ distances are 3.297(6) and 3.794(6) $\AA$, while the sum of antimony and oxygen van der Waals radii equals $3.70 \AA$ [13]. For comparison: in the bis(tetraphenylantimony) maleinate molecule the $\mathrm{Sb}-\mathrm{O}$ and $\mathrm{Sb} \cdots \mathrm{O}$ distances equal 2.206, $2.218 \AA$ and $3.236,3.259 \AA$ [2].

The torsion angle in the dicarboxylic acid anion $\mathrm{O}(2) \mathrm{C}(7) \mathrm{C}(10) \mathrm{O}(4)$ is $-50.3(7)^{\circ}$. Acetylene fragment has almost linear structure: the angles $\mathrm{C}(7) \mathrm{C}(8) \mathrm{C}(9)$ and $\mathrm{C}(10) \mathrm{C}(9) \mathrm{C}(8)$ are $177.8(7)^{\circ}$ and 175.2(7) ${ }^{\circ}$, the distance $\mathrm{C}(8)-\mathrm{C}(9)(1.177(9) \AA)$ corresponds to the triple bond.

The structural organization of the crystal is formed with the participation of weak hydrogen bonds of $(\mathrm{Ph}) \mathrm{C}-\mathrm{H} \cdots \mathrm{O}(=\mathrm{C})$ type.

\section{Conclusions}

Thus, the interaction between pentaphenylantimony with acetylenedicarboxylic acid has the specific feature: under mild conditions both carboxylic groups react. We did not succeed in isolation of acidic tetraphenylantimony carboxilate. Even short-duration heating of reaction mixture is accompanied by the decarboxylation of a carboxyl group in the acid and the formation of tetraphenylantimony propiolate.

In the bis(tetraphenylantimony) acetylenedicarboxilate molecule the carboxylate groups are characterized by the monodental type of the bond.

\section{References}

1. 1. Sharutin V.V., Sharutina O.K., Mel'nikova I.G., Fukin G.K., Zaharov L.N., Janovskij A.I., Struchkov Ju.T. Synthesis and Structure of Tetraphenylantimony Hydrogen Phthalate. Russian Chemical Bulletin. 1996, vol. 45, no. 8, pp. 1977-1980. DOI: 10.1007/bf01457791.

2. Sharutin V.V., Sharutina O.K., Pakusina A.P., Belsky V.K. Reactions of Pentaphenylantimony with Dicarboxyclic Asids. J. Organometal. Chem. 1997, vol. 536-537, no. 1-2, pp. 87-92. DOI: 10.1016/s0022-328x(96)06463-7.

3. Sharutin V.V., Senchurin V.S., Sharutina O.K. Synthesis and Structure of Tetraphenylantimony Hydrogenmalonate. Russian Journal of Inorganic Chemistry, 2014, vol. 59, no. 2, pp. 115-118. DOI: $10.1134 / \mathrm{S} 003602361402017 \mathrm{X}$.

4. Sharutin V.V., Sharutina O.K. Bis(tetraphenylantimony) Succinate, Malate and Tartrate: Synthesis and Structures. Russian Journal of Coordination Chemistry, 2014, vol. 40, no. 9, pp. 643-647. DOI: 10.1134/S1070328414090073.

5. Sharutin V.V., Sharutina O.K., Senchurin V.S., Platonova T.P., Nasonova N.V., Pakusina A.P., Gerasimenko A.V., Sergienko S.S. $\mu$-Oxo-bis(Tetraphenylantimony): Synthesis, Structure, and Reactions. Russian Journal of Coordination Chemistry, 2001, vol. 27, no. 9, pp. 669-675. DOI: 10.1023/a:1017909824029.

6. Sharutin V.V., Sharutina O.K., Bondar' E.A., Senchurin V.S., Pakusina A.P., Gatilov Ju.V., Adonin N.Ju., Starichenko V.F. Synthesis and Structure of Bis(tetraphenylantimony) Tetrafluorophthalate. Russian Journal of General Chemistry, 2002, vol. 72, no. 12, pp. 1920-1924. DOI: 10.1023/A:1023411228493. 
7. Millington P.L., Sowerby D.B. Phenylantimony (V) Oxalates: Isolation and Crystal Structures of $\left[\mathrm{SbPh}_{4}\right]\left[\mathrm{SbPh}_{2}(\mathrm{ox})_{2}\right],\left[\mathrm{SbPh}_{3}(\mathrm{OMe})\right]_{2} \mathrm{Ox}$ and $\left(\mathrm{SbPh}_{4}\right)_{2} \mathrm{Ox}$. J. Chem. Soc., Dalton Trans., 1992, no. 7, pp. 1199-1204.

8. Bruker (1998). SMART and SAINT-Plus. Versions 5.0. Data Collection and Processing Software for the SMART System. Bruker AXS Inc., Madison, Wisconsin, USA.

9. Bruker (1998). SHELXTL/PC. Versions 5.10. An Integrated System for Solving, Refining and Displaying Crystal Structures From Diffraction Data. Bruker AXS Inc., Madison, Wisconsin, USA.

10. Dolomanov O.V., Bourhis L.J., Gildea R.J., Howard J.A.K., Puschmann H. OLEX2: a Complete Structure Solution, Refinement and Analysis Program. J. Appl. Cryst., 2009, vol. 42, pp. 339-341. doi:10.1107/S0021889808042726.

11. Sharutin V.V., Sharutina O.K., Senchurin V.S. Tri- and Tetraphenylantimony Propiolates: Synthesis and Structures. Russian Journal of Coordination Chemistry, 2014, vol. 40, no. 2, pp. 109-114. DOI: $10.1134 / \mathrm{S} 1070328414020109$.

12. Ferguson G., Hawley D. M. The Crystal and Molecular Structure of $\mu$-CarbonatoBis(tetraphenylantimony): a System Containing Penta- and Hexacoordinated Antimony. Acta Crystallogr., 1974, vol. 30B, no. 1, pp. 103-111.

13. Cordero B., Gomez V., Platero-Prats A.E., Reves M., Echeverria J., Cremades E., Barragan F., Alvarez S. Covalent Radii revisited. Dalton Trans., 2008, pp. 2832-2838. DOI: 10.1039/b801115j.

Received 18 May 2015

\title{
ВЗАИМОДЕЙСТВИЕ ПЕНТАФЕНИЛСУРЬМЫ С АЦЕТИЛЕНДИКАРБОНОВОЙ КИСЛОТОЙ. МОЛЕКУЛЯРНАЯ СТРУКТУРА АЦЕТИЛЕНДИКАРБОКСИЛАТА БИС(ТЕТРАФЕНИЛСУРЬМЫ)
}

\author{
В.В. Шарутин, О.К. Шарутина, Ю.О. Губанова \\ Южно-Уральский государственный университет, г. Челябинск
}

\begin{abstract}
Взаимодействием пентафенилсурьмы с ацетилендикарбоновой кислотой (2:1 или 1:1 мольн.) в толуоле получен ацетилендикарбоксилат бис(тетрафенилсурьмы) (1). В молекуле 1 остаток кислоты выполняет мостиковую функцию, соединяя фрагменты $\mathrm{Ph}_{4} \mathrm{Sb}$. Атомы сурьмы имеют искаженную тригонально-бипирамидальную координацию с атомом кислорода в аксиальном положении. Длина связей $\mathrm{Sb}-\mathrm{O} 2.287(4)$ и

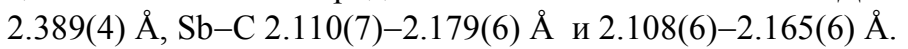

Ключевые слова: пентафенилсурьма, аџетилендикарбоновая кислота, аџетилендикарбоксилат бис(тетрафенилсурьмы), молекулярная структура, рентгеноструктурныцй анализ.
\end{abstract}

\section{Литература}

1. Синтез и строение кислого фталата тетрафенилсурьмы / В.В. Шарутин, О.К. Шарутина, И.Г. Мельникова и др. // Известия Академии наук. Серия Химическая. - 1996. - Т. 8. - Вып. 10. C. $2082-2085$.

2. Reactions of Pentaphenylantimony with Dicarboxyclic Asids / V.V. Sharutin, O.K. Sharutina, A.P. Pakusina et al. // J. Organometal. Chem. - 1997. - V. 536-537. - № 1-2. - P. 87-92. DOI: $10.1016 / \mathrm{s} 0022-328 \mathrm{x}(96) 06463-7$. 


\section{Organometallic chemistry}

3. Шарутин, В.В. Синтез и строение кислого малоната тетрафенилсурьмы / В.В. Шарутин, В.С. Сенчурин, О.К. Шарутина // Журн. неорган. химии. - 2014. - Т. 59. -№ 2. - С. 247-250. DOI: $10.7868 / \mathrm{S} 0044457 \mathrm{X} 14020184$.

4. Шарутин, В.В. Синтез и строение сукцината, малата и тартрата бис(тетрафенилсурьмы) / В.В. Шарутин, О.К. Шарутина // Корд. химия. - 2014. - Т. 40. - № 9. - С. 559-563. DOI: $10.7868 / \mathrm{S} 0132344 \mathrm{X} 14090072$.

5. Синтез, строение и реакции н-оксо-бис(тетрафенилсурьмы) / В.В. Шарутин, О.К. Шарутина, В.С. Сенчурин и др. // Корд. химия. - 2001. - Т. 27. - № 9. - С. 710-716.

6. Синтез и строение тетрафторфталата бис(тетрафенилсурьмы) / В.В. Шарутин, О.К. Шарутина, Е.А. Бондарь и др. // Журн. общ. химии. - 2002. - Т. 72. - № 12. - С. 2029-2032.

7. Millington, P.L. Phenylantimony (V) Oxalates: Isolation and Crystal Structures of $\left[\mathrm{SbPh}_{4}\right]\left[\mathrm{SbPh}_{2}(\mathrm{ox})_{2}\right],\left[\mathrm{SbPh}_{3}(\mathrm{OMe})\right]_{2} \mathrm{Ox}$ and $\left(\mathrm{SbPh}_{4}\right)_{2} \mathrm{Ox}$. / P.L. Millington, D.B. Sowerby // J. Chem. Soc., Dalton Trans. - 1992. - N. 7. - P. 1199-1204.

8. Bruker (1998). SMART and SAINT-Plus. Versions 5.0. Data Collection and Processing Software for the SMART System. Bruker AXS Inc., Madison, Wisconsin, USA.

9. Bruker (1998). SHELXTL/PC. Versions 5.10. An Integrated System for Solving, Refining and Displaying Crystal Structures From Diffraction Data. Bruker AXS Inc., Madison, Wisconsin, USA.

10. OLEX2: a Complete Structure Solution, Refinement and Analysis Program / O.V. Dolomanov, L.J. Bourhis, R.J. Gildea et al. // J. Appl. Cryst. - 2009. - V. 42. - P. 339-341. DOI: $10.1107 /$ S0021889808042726.

11. Шарутин, В.В. Синтез и строение пропиолатов три- и тетрафенилсурьмы / В.В. Шарутин, О.К. Шарутина, В.С. Сенчурин // Корд. химия. - 2014. - Т. 40. - № 2. - С. 108-112. DOI: $10.7868 / \mathrm{S} 0132344 \mathrm{X} 14020108$.

12. Ferguson, G. The Crystal and Molecular Structure of $\mu$-Carbonato-Bis(tetraphenylantimony): a System Containing Penta- and Hexacoordinated Antimony / G. Ferguson, D.M. Hawley // Acta Crystallogr. - 1974. - V. 30B. - N. 1. - P. 103-111.

13. Covalent Radii revisited / B. Cordero, V. Gomez, A.E. Platero-Prats et al. // Dalton Trans. 2008. - P. 2832-2838. DOI: 10.1039/b801115j.

Шарутин Владимир Викторович - доктор химических наук, профессор, старший научный сотрудник УНИД, Южно-Уральский государственный университет. 454080, г. Челябинск, пр. им. В.И. Ленина, 76. Е-mail: vvsharutin@rambler.ru

Шарутина Ольга Константиновна - доктор химических наук, профессор, кафедра аналитической химии, Южно-Уральский государственный университет. 454080, г. Челябинск, пр. им. В.И. Ленина, 76. E-mail: sharutinao@mail.ru

Губанова Юлия Олеговна - студент химического факультета, Южно-Уральский государственный университет. 454080, г. Челябинск, пр. им. В.И. Ленина, 76. Е-mail: ulchik_7757@mail.ru

Поступила в редакцию 18 мая 2015 2.

\section{ОБРАЗЕЦ ЦИТИРОВАНИЯ}

Sharutin, V.V. Interaction of pentaphenylantimony with acetylenedicarboxylic acid. Molecular structure of bis(tetraphenylantimony) acetylenedicarboxilate / V.V. Sharutin, O.K. Sharutina, Yu.O. Gubanova // Вестник ЮУрГУ. Серия «Химия». - 2015. - Т. 7, № 4. - С. 17-22. DOI: $10.14529 /$ chem 150403

\section{FOR CITATION}

Sharutin V.V., Sharutina O.K., Gubanova Yu.O. Interaction of Pentaphenylantimony with Acetylenedicarboxylic acid. Molecular Structure of Bis(tetraphenylantimony) Acetylenedicarboxilate. Bulletin of the South Ural State University. Ser. Chemistry. 2015, vol. 7, no. 4, pp. 17-22. DOI: $10.14529 /$ chem 150403 